\title{
Multi Sided Platforms (MSPs) Value Captation and Monetization Strategies: A Strategic Management Perspective
}

\begin{abstract}
Vincent Sabourin
Director of the Observatory on Commercialization and Strategies of Innovation, ESG School of Management, University of Quebec at Montréal (UQAM), 315 east St-Catherine Montreal Qc., Canada
\end{abstract}

Tel: 1-514-947-3993Ｅ-mail: sabourin.vincent@ uqam.ca

Received: April 18, 2016 Accepted: April 25, 2016 Published: June 22, 2016

doi:10.5296/bms.v7i1.9332 URL: http://dx.doi.org/10.5296/bms.v7i1.9332

\begin{abstract}
The fundamental basis of all multisided business platforms is the value proposition offered to consumers, on one hand, and to business buyers, on the other hand, and so our starting point must be with the fundamentals concerning the management of value propositions. The competitive strategies of monetization and value creation include: Envelopment, overlapping, freemium, advertising and asymmetry information methods. In this paper, we allude that multisided platforms to play the role of resource integrators, involving consumers and business partners in a process of co-creation of value - an integrated, a networked business model. This is primarily due to a shift in the relative influence of different business stakeholders in the context of the business modeling of two-sided multisided platforms.
\end{abstract}

Keywords: Product envelopment, Overlapping strategy, Freemium strategy, Platform monetization 


\section{Introduction}

Multi-sided platforms, known also as multi-sided markets, are an important business phenomenon that has proliferated with the rise of information technology and the Internet. Two-sided platforms are specific multi-sided platforms that bring together two distinct but interdependent groups of customers. They create value as intermediaries by connecting these groups (Osterwalder, Pigneur, \& Smith, 2010). Today, a systematic approach to business models is more widespread and the survival rate of new online businesses is correspondingly better. Well-constructed business models identify a target consumer audience and a clear value proposition, they also specify the structure of the value network, a revenue generating mechanism, and they estimate the cost structure and profit potential of their business (Chesbrough, 2010). The business model is therefore a structural template that describes the organization of a firm's transactions with its external business partners in factor markets as well as with its consumer audience or product market (Lindgreen, Hingley, Grant, \& Morgan, 2012). In other words, the business model is "the rationale of how an organization creates, delivers and captures value" (Osterwalder, Pigneur, \& Smith, 2010). Multi Sided Platforms (MSPs) have existed for centuries - for instance of village market and matchmakers (Hagiu, 2007). However, according to Seamans and Zhu (2010) multisided platform prominence has soared only recently, mostly because of monetary value; it offers to players, which has tremendously increased the opportunities for building larger, more valuable and powerful platforms. At the same time, Zhu and Iansiti (2012) assert that, by expanding the potential scope of platforms, technology has also increased the number and complexity of the factors -economic and technical- that drive the strategic design of MSPs into different products and markets; acts which serve as competitive driver.

In many of today's businesses, especially those mediated by information technologies, platforms are where multiple, interested parties meet each other to fulfill transactions. Examples of platform-mediated businesses abound: Internet search engines, auctioneers, credit cards, and dating services, to name only a few (Seamans \& Zhu, 2010). There are many products or services which are one-sided, i.e. cater to only one customer group, but which hold the potential to be expanded into an MSP by offering to reduce the costs associated with transactions between their existing customers and new customer groups (Hagiu, 2006). As argued by the authors (MacCormack and Iansiti, 2009) the value captation of MSP's starts with spotting such new customer groups that can be linked to the profitably of an established platform.

As argued by Seamans and Zhu (2010), technology in particular has greatly expanded the range of creative levers that one-sided businesses can come up with in order to expand into unexpected directions, oftentimes with disruptive effects. In terms of practical relevance, Google is credited with pioneering the now established Internet business model of associating sponsored links to search results (Bruno, 2011). Indeed, Google itself started as a one-sided search service but quickly realized that the technology which it used to enable consumers to search the web could also be used to reduce search costs between advertisers and consumers, hence the creation of AdWord and AdSense (Bruno, 2011), the programs which allow Google to offer and charge for search-related advertising. This invention was a quantum leap in multi 
sided platform, which many scholars and practitioners view has contributed to cost reduction and value addition (Weyl, 2010; Edelman, 2012; Rysman, 2009).

\subsection{Research Objective}

Our research objective was to review the literature on the topic of value captation and monetization strategies on multisided-platforms to develop a strategic management framework. More specifically the objectives were:

- $\quad$-to review value captation and monetization strategies

- $\quad$-integrate the research literature on value captation and monetization strategies of MSP's in a strategic management framework

\section{Research Model: Literature Review}

The approach in this research is theoretical in nature, reviewing the latest publications on the subject under study and no empirical studies are carried out.

\subsection{Monetization Approaches in Multisided Business Platforms}

"Monetization," the means by which companies generate revenues, is described as multisided most intractable problem because as there is no "one size fits all" solution to monetize in MSPs (Shah et al., 2015). According to Kwon and Hong (2015), succeeding in a complex, fast changing, and partner-centric environment require adjustments to how given players approach the market. The makeup of a company's value chain and the expectations of its partners and customers are different in a multisided business model (Yang et al., 2015). There are different methods of value addition that are being adopted by players in MSP to generate revenue and make income from their platform technologies.

\subsubsection{Freemium Strategy}

According to Pujol (2015), Freemium is a contraction of the words 'free' and 'premium', the latter characterizing a privileged offer. This approach builds on the fact that some features of multisided platforms are excludable (Pujol, 2015; Hockensen, 2013). The idea is then to apply menu pricing (i.e., second-degree price discrimination) by proposing different versions of the service at different prices. Typically, a free version (giving basic access to MSP) can be offered along a number of paid versions (including various bundles of excludable services, such as personalized marketing, privileged interactions with marketers, unlimited access to platforms at any time, more flexibility in the use of the platform, etc) (Bharadwaj, et al., 2015). The Freemium approach goes beyond menu pricing as the free version is not just meant to identify users with a low willingness to pay, but more importantly to induce them to 'convert' to the paid version, whose value would be revealed by the use of the free version (Alkoby et al., 2015). Although this approach has proven to be successful for many Internet-based services, some specialists of multisided platform cast doubt on its replicability (Mehta et al., 2015). Competition between networked platforms is quite intense as platforms are not really differentiated (nor horizontally nor vertically) and users face low switching costs (Tan et al., 2015). Costs associated with the paid services also decrease the scalability of 
multisided platform (for instance, more designers and technicians would need to be hired) (Tan et al., 2015). These two forces inevitably reduce the margins that can be made from this revenue approach (Osterwalder et al., 2015). In addition, this will decrease the openness of MSP platforms while both professors and students derive value from it (Mehta et al., 2015). It is indeed likely that players would invest much less in MSPs" than in alternative network technologies (Kumar, 2014). If experts leave the platform, consumers will follow, leading to further negative feedback effects.

\subsubsection{Above the Line Strategy (Advertising Model)}

According to Weyl (2010), above the line approach is one of the most preferred paths to monetization in the Internet sector, particularly as relates to the application s of multisided platform. The model can be summarized as follows: platforms do not sell contents to users directly but only indirectly, as contents serve to attract users, whose attention (and/or information) is then sold to advertisers. Advertisers are indeed willing to pay to attract eyeballs on their ads, and even more if they know to whom these eyes belong. In this respect, multisided platforms are of interest to advertisers thanks to the information that they can collect about their users and the large amount of time that students spent on the platform (Ballantyne. et al., 2011). This model seems promising at first glance. However, it is important to evaluate the extent to which advertisements can interfere with the learning process and, possibly, discourage students (Bharadwaj et al., 2015; Tan et al., 2015; Alkoby et al., 2015). In the language of multisided platforms, one would then say that the group of advertisers exerts a negative indirect network effect on the group of students (Osterwalder et al., 2011).

\subsubsection{Asymmetrical Monetization Strategy}

As for the advertising model, the job matching model takes advantage of the presence of private actors around the platform and the by-product created by MSPs, i.e., the information about its users (Adner et al., 2015). Asymmetric information problems are present in the labor market: an efficient pairing between the two sides of the market is difficult to achieve as players lack reliable information about potential customers and vice versa. Platform players can in-deed increasingly resort to new tools that allow applicants to demonstrate their abilities and skills in a more coherent and effective way. It is in this context that MSP platforms can play a creative role (Jeitschko \& Tremblay, 2015). By continuously monitoring the behavior of students, multisided platforms accumulate big data that they can use to improve matching on the job market. Such service can be monetized on both sides of the market (Gazz et al., 2015). By drawing an accurate and multidimensional profile of their customers, multisided platforms can help employers in their recruitment process (Mehta et al., 2015). Platforms can also mine their data to better advice customers and help them to present their needs in a more convincing way, thereby facilitating job enrichment (Tan et al., 2015).

\subsection{Monetization Function of Multisided Platforms}

Ralf and Roesch (2012) identified important value creating class of businesses that are now generally referred to as "Multi-sided platforms". Multi-sided platforms create value by 
bringing two or more different types of economic agents together and facilitating interactions between them that make all agents better off (Ke, and Pan, 2011; Helmut et al., 2012; Ralf and Roesch, 2012). In general economic context, scholars have cited that multi sided platforms have capitalized many economically important industries including payments, mobile phones, financial exchanges, advertising-supported media, and various Internet-based industries (Evans, 2009; Helmut et al., 2012). Recent years have seen the emergence of management research on multi-sided platforms (MSPs), regarding their strategies and business models that can be adopted to generate revenue and contribute to platform monetization (Maziar, 2014). The fundamental monetization function of multisided platforms is its capacity to become a transactional agent on each side to interact in a valuable way with economic agents on other sides. As Evans (2010) argues, these platforms facilitate value-creating exchanges in the face of transaction costs or other obstacles to trade, which would normally prevent the two sides from interacting to generate revenue.

The platform plays a key role in creating these indirect economic network effects. In fact, as described in Evans and Schmalensee (2010), the major challenge for aspiring platforms is to get enough economic agents on each side to secure enough critical mass to propel indirect network effects. Platforms generate indirect economic network effects, and thus value for the economic agents they aspire to serve, through pricing, product design, marketing, and other efforts to attract agents on each side (Wang and Ma 2015). Jullien (2011), for instance, has stressed the value of "divide and conquer" strategies for a startup or an entrant challenging an established platform: subsidize agents in the most price-sensitive group, and then use their participation to attract agents in the other group. From a management perspective, these indirect network externalities play an important role for a strategic analysis of multi-sided platforms. For traditional one-sided industries, analysts ordinarily assume that demand depends on the price of the product as well as the prices of complements and substitutes (Roger et al., (2014). One of the major contributions the multi-sided platform literature has made to industrial organization has been to demonstrate that indirect network effects are important across a wide range of industries - from low-tech industries such as shopping malls to high-tech ones such as mobile phone operating systems (Salazar, 2015).

In simple models, indirect network effects can also produce demand-side economies of scale that lead to monopoly: increased participation on one side of the platform makes it more attractive to the other side, leading to increased participation there, making participation by the first side more attractive (Roger et al., 2014; Evans, 2009). Multi-sided platforms coordinate the demand of distinct groups of customers who need each other in some way (Evans, 2003; Evans, 2013). Competition among platforms takes place when seemingly distinct customer groups are connected through interdependent demand and a platform that, acting as an intermediary, internalizes the resulting indirect network externalities (Ke, and Pan, 2011). Platforms are central to many key industries including computer games, information technology, many internet-based industries, media, mobile telephony and other telecommunications industries, and payment systems (Evans, 2003). 


\subsection{Value Appropriation Strategy in Multisided Platform}

The value proposition is at the heart of business models (Osterwalder, Pigneur, \& Smith, 2010; Lindgreen, Hingley, Grant, \& Morgan, 2012), as it is also at the heart of marketing strategies (Osterwalder et al., 2010). Hence it is de facto the bridge between strategic management and marketing literatures. The concept of value proposition is enhanced by key strategies which can be used by players to generate revenues and monetize the entire platform.

\subsubsection{Envelopment Strategy}

Platform markets comprise a large and rapidly growing share of the global economy (Yang et al., 2015). In platform markets, strong network effects and high switching costs often shelter incumbents from entry (Eisenmann et al., 2010). To overcome entry barriers, new platform providers generally must offer revolutionary functionality (Shah et al., 2015).

One of the key strategy surveyed in the literature include Envelopment strategy, as strategy where Envelopment entails entry by one platform provider into another's market by bundling its own platform's functionality with that of the target's so as to leverage shared user relationships and common components (Wismor, 2015; Kwon \& Hong, 2015). Envelopment consists of two stages. First, as in the indirect attack, the aggressor focuses on a specific market segment for a point of entry. Then, by identifying additional market segments and adding new products, it uses an expansion strategy to envelop the entire market. Eisenmann et al., (2010) state that platform providers that serve different markets sometimes have overlapping user bases and employ similar components. Envelopment entails entry by one platform provider into another's market by bundling its own platform's functionality with that of the target's so as to leverage shared user relationships and common components (Kwon and Hong, 2015). Shah et al., (2015) assert that dominant firms that otherwise are sheltered from entry by standalone rivals due to strong network effects and high switching costs can be vulnerable to an adjacent platform provider's envelopment attack. Due to network effects and switching costs in platform markets, entrants generally must offer revolutionary functionality to win substantial market share. According to Eisenmann et al., (2010), through envelopment, a provider in one platform market can enter another platform market, and combine its own functionality with that of the target in a multi-platform bundle that leverages shared user relationships. Yang et al., (2015) state that envelopers capture market share by foreclosing an incumbent's access to users; in doing so, they harness the network effects that previously had protected the incumbent.

\subsection{Monetization Returns, Value Creation and Value Appropriation}

Caskey (2015), states that appropriate pricing, support and incentives for participants are critical success elements for any platform. A key question is whether any particular side requires subsidization and, if so, which one (Singla and Apoor, 2015; Wismor, 2015). Based on the history of past platforms from a variety of industries, the most price and/or quality sensitive participants and those with high visibility or attractiveness appear to be the strongest candidates for subsidization (Samarrokhi et al., 2015). Fragidis and Tarabanis (2011) argue that 
a firm able to leverage vendor relationships with one side may not have to provide strong subsidies. As for pricing, network economies of scale mean that under pricing platform participation will lead to suboptimal platform profitability; overpricing participation for any one participant will choke off growth and leave room for competitors to gain a stronger foothold in the marketplace (Archer-Brown et al., 2013; Wismor, 2015; Frank, 2015; Li, 2015). The dual processes of value creation and value appropriation represent crucial elements of competitive strategy for both firms and individuals (Rintamaki and Nitronen, 2015. Accordingly, the value creation/value appropriation framework has become commonly deployed in both research and teaching in a diverse set of fields including strategy (Soumaya, 2013; Czarniewski, 2015). The creation of new value lies at the heart of economic development and a population's adaptive efficiency (Wagner, Eggert and Lindermann, 2010). Value creation results from actions that entail the novel combination and exchange of resources, by which resources are diverted from known applications to be deployed in new contexts (Chatain, 2010; Doligaski, 2015). To the extent that resources are diverted away from their best known uses, novel combinations may be allocatively inefficient (Lariviere et al., 2013; Frank, 2015). Over time, however, new combinations enable the discovery of new uses for resources, thereby leading to an increase in what has alternatively been called adaptive efficiency, which according to Lepak, Smith and Taylor (2007) is the foundation of value creation. The concept of value that has not been realized or appropriated is highly abstract (Coff, 2010; Czarniewski, 2015). While value appropriation is generally visible in the form of revenue streams such as shareholder returns, executive compensation, and labor contracts, the creation of uncaptured value is substantially more difficult to identify, much less quantify (Czarniewski, 2015; Czarniewski, 2015). As a result, the notion of value creation often takes on a nebulous and indeterminate nature, leading some to utilize terms such as 'potential value' (Coff, 2010), 'intrinsic value' (Porter, 1991), and 'bundles of potentiality' (Pitelis, 2009). Managers and researchers alike may legitimately wonder why they should be concerned with the value creation process when only value appropriation impacts the bottom line. Value creation may be relevant to fields such as new growth theory within economics (Bacache et al., 2015; Gimpel, 2015; Czarniewski, 2015). Soumaya (2013) cites that value creation often entails the development of strategic resources. When successful, R\&D initiatives result in technological capabilities, inter-organizational collaborative efforts such as joint ventures and alliances lead to the creation of social capital, intra-organizational collaboration leads to social capital and organizational culture, and a successful product launch leads to the establishment of brand-name capital (Chatain, 2010; Czarniewski, 2015; Wismor, 2015). Most of these resources cannot be easily purchased in factor markets, but must be built through new combinations undertaken within and between firms (Campbell and Mohl, 2015). An emphasis on resources and capabilities adds substance to the otherwise opaque concept of new value creation, since newly created, unappropriated value may become embedded in resources which may in turn be amenable to valuation techniques (Auer and Petit, 2015). Value appropriation often entails the extraction of value that is embedded in resources (Picard, 2015). Resources exhibit stickiness in accumulation (Dierickx, Kraemer and Linden, 2009) as well as in exploitation. Soumaya (2013) assert that to convert resources into appropriated value (i.e., utility) requires time; therefore, appropriation is more a process, 
not an event. Value is ultimately appropriated by individuals (i.e., shareholders, employees, executives, middle-level managers, customers, other stakeholders), but other than customers and external stakeholders, these individuals are generally nested within firms that in turn are nested within a population (Soumaya, 2013).

Dedrick et al., (2009) states that value appropriation, then, is comprised of two related processes: inter-organizational value appropriation (i.e., how value is distributed among the firms within a population) and intra-organizational value appropriation (i.e., once value is appropriated by a firm, how that value is distributed among the firm's internal stakeholders). Substantial opportunities exist for further review into value creation and value appropriation processes, as well as the interaction between these processes (Pitelis, 2009; Czarniewski, 2015). In terms of value creation, the primary barrier to empirical research is that value is difficult to measure in an un-appropriated form (Valverde et al., 2015). In terms of value appropriation, significant contributions in management and other fields have shed light on how appropriated value is distributed between firms (Yang et al., 2015). In contrast, very little research has focused on value appropriation within firms (Soumaya, 2013, Hitt et al., 2011).

\section{Discussion, Implications and Conclusion}

In our literature analysis, we have established that companies thinking to monetize and create value from a multisided platform model must be confident that the business model embraced is easily scalable to generate substantial revenue (Contini and Lanzara, 2009; Leidner et al., 2011). Potential platform owners leveraging a vendor relationship to get a leg up on competitors should critically examine whether their current customer base is sizable enough to ensure this advantage can provide a meaningful head start and whether other territories can be easily integrated into the same side of the platform (Wagner, et al., 2010; Chatain and Zemsky, 2011). Multiple authors emphasize the importance of network effects that are required for the adoption of the platform (Basole and Karla, 2012; Chen and Hit, 2005; Tuunainen et al., 2011). To begin with, the network effects are created when users are seeking compatibility with the other users (Farrell and Klemperer, 2007; Wagner, et al., 2010; Chatain and Zemsky, 2011). There is an emergence of economies of scope and economies of scale when more consumers purchase technologically compatible products (Verganti, 2009). Therefore, product has network effects not only if there are individual benefits related to the product, but also additional benefits if other consumers having the same or compatible product (Afuah, 2013). The technology compatibility within different devices can also be translated into external network effects that lead to positive externalities between users (Cusumano, 2010; Salazar, 2015; Lin et al., 2014). The retention of existing consumers can be related to the degree of control the platform providers are exercising over their platforms (Park, 2014). The closed platform architecture gives more control to the product provider in controlling the user experience. The cross side network effect is crucial for platform survival (Kivleniece and Quelin, 2012). The same side network effects are further weakened by the fact that majority of high-status complementors are working on multiple platforms and their applications have cross-platform functionality (Bouderau and Jepessen, 2014). As argued by Coff (2010), these platforms can generate greater external network effects as part of a larger ecosystem that 
generally consists of several business entities: mobile phone manufacturers, mobile platform providers, mobile network operators and mobile application providers (Ware, 2009). Platforms supported by a global ecosystem of complementors and strong network effects should be more difficult for competitors to dislodge than standalone products that are more subject to competition based on fashion or price (Soumaya, 2013). But even the best firms face a potential challenge similar to that described by Soumaya (2013). Success ties a firm to its existing customers as well as products and business models associated with those customers. This makes it difficult for a firm to change its products or its platform, even though these probably need to evolve lest they become obsolete. From our theoretical review and analysis, we noted that important area of further research is that of the emergence and evolution of business ecosystems (Greenstein, 2009). According to Cusumano (2011), the networks approach from the organizational literature, by bringing its insights on network dynamics and field evolution is well-positioned to make significant contributions in this area. In particular, recent work by Nambisan and Sawhney (2011), building on Dhanaraj and Parkhe (2006), develops explicitly the link between two sided platform leadership and orchestration processes in network-centric innovation. The new institutional literature rooted in sociology offer concepts such as legitimacy, collective identity, and institutional work, which can be useful to determine whether and how multisided platform leaders can successfully establish themselves as trustworthy brokers (Gawer, 2010; Nambisan and Sawhney, 2011). In our research, we have established that (economics, innovation, operations, strategy), technological platforms are associated with a positive impact on innovation. The positive effect stems from the fact that, by offering unified and easy ways to network among common components and foundational technologies, platform leaders help reduce the cost of entry in complementary markets, and provide demand for complements, often fuelled by network effects (Perrons, 20009; Cusumano, 2010; Gawer, 2009a). Platforms offer therefore a setting where it is in the interest of private firms to elicit and encourage innovation by others.

\section{Conclusion}

Today, a systematic approach to business models is more widespread and the survival rate of new multisided platform businesses is correspondingly better. Well-constructed business models identify a target consumer audience and a clear value proposition, they also specify the structure of the value network, a revenue generating mechanism, and they estimate the cost structure and profit potential of their business (Chesbrough, 2010). The business model is therefore a structural template that describes the organization of a firm's transactions with its external business partners in factor markets as well as with its consumer audience or product market. In other words, the business model is "the rationale of how an organization creates delivers and captures value.

\section{References}

Altman, E. J., Nagle, F., \& Tushman, M. (2014). Innovating without Information Constraints: Organizations, Communities, and Innovation When Information Costs Approach Zero. Harvard Business School Organizational Behavior Unit Working Paper, (14-043). 
Archer-Brown, C., Piercy, N., \& Joinson, A. (2013). Examining the information value of virtual communities: Factual versus opinion-based message content. Journal of Marketing Management, 29(3-4), 421-438.

Asongu, S. A., \& De Moor, L. (2015). Recent advances in finance for inclusive development: a survey. Recent Advances in Finance for Inclusive Development: A Survey (March 9).

Asonguab, S. A., \& De Moora, L. (2015). AGDI Working Paper.

Auer, D., \& Petit, N. (2015). Two-Sided Markets and the Challenge of Turning Economic Theory into Competition Policy. Available at SSRN 2552337.

Avital, M. Peer-to-Peer Service Sharing Platforms: Driving Share and Share Alike on a Mass-Scale. In The 34th International Conference on Information Systems. ICIS 2013.

Bacache, M., Bloch, F., Bourreau, M., Caillaud, B., Cremer, H., Crémer, J., ... \& Lozachmeur, J. M. (2015). Taxation and the digital economy: A survey of theoretical models.

Belleflamme, P., \& Jacqmin, J. (2014). An economic appraisal of MOOC platforms: business models and impacts on higher education. Available at SSRN 2537270.

Belleflamme, P., \& Lambert, T. (2014). Crowdfunding: Some Empirical Findings and Microeconomic Underpinnings. Available at SSRN 2437786.

Bhargava, H. K. (2014). Platform technologies and network goods: insights on product launch and management. Information Technology and Management, 15(3), 199-209.

Block, J. H., Kohn, K., Miller, D., \& Ullrich, K. (2015). Necessity entrepreneurship and competitive strategy. Small Business Economics, 44(1), 37-54.

Bonakdar, A. (2015). Business Model Innovation (Doctoral dissertation, University of St. Gallen).

Boudreau, K. J., \& Jeppesen, L. B. (2014). Unpaid crowd complementors: The platform network effect mirage. Strategic Management Journal.

Bruno, J., (2011). Competition in Multi-Sided Markets: Divide and Conquer. American Economic Journal, Microeconomics, 3(4), 186-219.

Campbell, R., \& Mohl, L. (2015). Leadership and Quality Improvement. In Pediatric and Congenital Cardiac Care (pp. 229-237). Springer London.

Caskey, K. R. (2015). Competitive strategies for small manufacturers in high labor cost countries: Boutique ski manufacturers in the US. Competitiveness Review: An International Business Journal, 25(1).

Chakravarty, A., Kumar, A., \& Grewal, R. (2014). Customer Orientation Structure for Internet-Based Business-to-Business Platform Firms. Journal of Marketing, 78(5), 1-23.

Chakravarty, A., Kumar, A., \& Grewal, R. (2014). Customer Orientation Structure for Internet-Based Business-to-Business Platform Firms. Journal of Marketing, 78(5), 1-23. 


\section{Macrothink}

Chatain, O. (2010). Value creation, competition, and performance in buyer-supplier relationships. Strategic Management Journal, 32, 76-102.

Chatain, O., \& Zemsky, P. (2011). Value creation and value capture with frictions. Strategic Management Journal, 32, 1206-1231.

Cheng, M., Green, W. J., \& Ko, J. C. W. (2015). The Impact Of Strategic Relevance And Assurance Of Sustainability Indicators On Investors'decisions. Auditing: A Journal Of Practice And Theory.

Coff., R. (2010). The coevolution of rent appropriation and capability development. Strategic Management Journal, 31, 711-733.

Contini, F., \& Lanzara, G., F. (2009). ICT and Innovation in the Public Sector: European Studies in the Making of E-Government. New York: Palgrave Macmillan.

Cusumano, M. A. (2010). The evolution of platform thinking. Communications of the ACM, 53(1), 33-35.

Cusumano, M. A. (2011). 'The platform leader's dilemma'. Communications of the ACM, 54(10), 21-24.

Czarniewski, S. (2015). Shaping The Business Model and The Value of The Enterprise. European Journal of Research and Reflection in Management Sciences, 3(1).

Dedrick, J., Kraemer, K. L., \& Linden, G., (2009). Who profits from innovation in global value chains?: A study of the iPod and notebook PCs. Industrial and Corporate Change, 19, 81-116.

Doligalski, T. (2015). Conceptual Model of Internet-Based Customer Value Management. In Internet-Based Customer Value Management (pp. 81-140). Springer International Publishing.

Doligalski, T. (2015). Financial Aspects of Customer Value Management. In Internet-Based Customer Value Management (pp. 141-152). Springer International Publishing.

Edelman, B., (2012). Using Internet Data for Economic Research. Journal of Economic Perspectives, 26(2), 189-206.

Edelman, B., G., Sonia J., \& Kominers, S., D. (2011). To Groupon or Not to Groupon: The Profitability of Deep Discounts. Harvard Business School NOM Unit Working Paper No. $11-063$.

Evans, D. S. (2010). The Web Economy, Two-Sided Markets, and Competition Policy, Concurrences Competition Laws Journal, 2010(2).

Evans, D. S., \& Schmalensee, R. (2010). Failure to Launch: Critical Mass in Platform Businesses. Review of Network Economics, 9(4). 1-26.

Evans, D., S. (2009). The Online Advertising Industry: Economics, Evolution, and Privacy. Journal of Economic Perspectives, 23(3), 37-60. 
Fragidis, G., \& Tarabanis, K. (2011, March). Analyzing value co-creation in service systems: contribution from GORE. In Proceedings of the 2011 ACM Symposium on Applied Computing (pp. 705-707). ACM.

Frank, J. S. (2015). Competition Concerns in Multi-Sided Markets in Mobile Communication. In Competition on the Internet (pp. 81-99). Springer Berlin Heidelberg.

Frank, J. S. (2015). Competition Concerns in Multi-Sided Markets in Mobile Communication. In Competition on the Internet (pp. 81-99). Springer Berlin Heidelberg.

Gawer, A. (2009). Platforms, Markets and Innovation (Ed.). Cheltenham, UK and Northampton, MA, US: Edward Elgar.

Gawer, A. (2009a). 'Platforms dynamics and strategies: From products to services', in Gawer, A. (ed.), Platforms, Markets and Innovation, 45-76. Cheltenham, UK and Northampton, MA, US: Edward Elgar.

Gawer, A., \& Cusumano, M. A. (2014). Industry platforms and ecosystem innovation. Journal of Product Innovation Management, 31(3), 417-433.

Gawer, A., \& Cusumano, M. A. (2014). Industry platforms and ecosystem innovation. Journal of Product Innovation Management, 31(3), 417-433.

Gimpel, G. (2015). The Future of Video Platforms: Key Questions Shaping the TV and Video Industry. International Journal on Media Management, (ahead-of-print), 1-22.

Greenstein, S. (2009). 'Open platform development and the commercial Internet', in Gawer, A. (ed.), Platforms, Markets and Innovation, Cheltenham, UK and Northampton, MA, US: Edward Elgar, pp. 219-248.

Hanseth, O., \& Lyytinen, K. (2010). Design theory for dynamic complexity in information infrastructures: The case of building internet. Journal of Information Technology, 25(1), 1-19, 2010.

Helmut, D., Duschl, T., Egon, F., \& Lang, M. (2012). A Contest Model of a Professional Sports League with Two-Sided Markets. Journal of Economics and Statistics, 232(3), 336-359.

Hitt, M. A., Ireland, R. D., Sirmon, D. G., \& Trahms, C. A. (2011). Strategic entrepreneurship: Creating value for individuals, organizations and society. Academy of Management Perspectives, 25, 57-75.

Jeitschko, T. D., \& Tremblay, M. J. (2014). Homogeneous platform competition with endogenous homing (No. 166). DICE Discussion Paper.

Jeitschko, T. D., \& Tremblay, M. J. (2015). Platform Competition with Endogenous Homing.

Jullien, B. (2011). Competition in Multi-Sided Networks: Divide-and-Conquer. American Economic Journal: Microeconomics, 3(4), 1-35.

Ke, D., \& Pan, J. (2011). Platforms, Network Effects, and Small Business Dynamics in China: 
Case Study of the Shanzhai Cell Phone Industry, IDE Discussion Paper, No. 302.

Kivleniece, I., \& Quelin, B. V. (2012). Creating and capturing value in public-private ties: A private actor's perspective. Academy of Management Review, 37, 272-299.

Larivière, B., Joosten, H., Malthouse, E. C., van Birgelen, M., Aksoy, P., Kunz, W. H., \& Huang, M. H. (2013). Value fusion: the blending of consumer and firm value in the distinct context of mobile technologies and social media. Journal of Service Management, 24(3), 268-293.

Leidner, D., E., Lo, J., \& Preston, D. (2011). An empirical investigation of the relationship of IS strategy with firm Performance. The Journal of Strategic Information Systems, 20(4), 419-437.

Lepak, D. P., Smith, K. G., \& Taylor, M. S. (2007). Value creation and value capture: A multilevel perspective. Academy of Management Review, 32, 180-194.

Li, J. (2015). Is online media a two-sided market?. Computer Law \& Security Review, 31(1), 99-111.

Lin, M., Wu, R., \& Zhou, W. (2014). Platform Pricing with Endogenous Network Effects. Available at SSRN 2426033.

MacCormack, A., D, \& Iansiti, M. (2009). Intellectual property,architecture, and the management of technological transitions: evidence from Microsoft Corporation. Journal of Product Innovation Management, 26, 248-263.

Mäkinen, S. J., Seppänen, M., \& Ortt, J. R. (2014). Introduction to the Special Issue: Platforms, Contingencies and New Product Development. Journal of Product Innovation Management, $31(3), 412-416$.

Malhotra, A., \& Van Alstyne, M. (2014). The dark side of the sharing economy... and how to lighten it. Communications of the ACM, 57(11), 24-27.

McGregor, J. D., \& da Silva Amorim, S. (2014). Ecosystem Business Models and Architectures. WDES 2014, 33.

Morandi, V., Malighetti, P., Paleari, S., \& Redondi, R. (2015). Codesharing agreements by low-cost carriers: An explorative analysis. Journal of Air Transport Management, 42, 184-191.

Nambisan, S., \& Sawhney, M. (2011). 'Orchestration processes in network-centric innovation: Evidence from the field'. Academy of Management Perspectives, August, 40-57.

Novani, S., \& Kijima, K. (2012). Value co-creation by customer-to-customer communication: social media and face-to-face for case of airline service selection.

Osterwalder, A., Pigneur, Y., Bernarda, G., \& Smith, A. (2015). Value Proposition Design: How to Create Products and Services Customers Want. John Wiley \& Sons.

Park, E. J. (2014). Creating a sustainable business model for the TV industry: strategic analysis on the Smart TV ecosystem (Doctoral dissertation, Massachusetts Institute of 
Technology).

Parker, G., \& Van Alstyne, M. W. (2014). Platform Strategy. Boston U. School of Management Research Paper, (2439323).

Parker, G., \& Van Alstyne, M. W. (2014). Platform Strategy. Boston U. School of Management Research Paper, (2439323).

Perrons, R. K. (2009). The open kimono: How Intel balances trust and power to maintain platform leadership. Research Policy, 38, 1300-1312.

Peterson, M., Gröne, F., Kammer, K., \& Kirscheneder, J. (2010). Multi-channel customer management: delighting consumers, driving efficiency. Journal of Direct, Data and Digital Marketing Practice, 12(1), 10-15.

Picard, R. G. (2015). 7. Economics of print media. Handbook on the Economics of the Media, 151.

Picard, R. G., \& Wildman, S. S. (Eds.). (2015). Handbook on the Economics of the Media. Edward Elgar Publishing.

Pitelis, C. N. (2009). The co-evolution of organizational value capture, value creation and sustainable advantage. Organization Studies, 31, 1115-1139.

Podszun, R. (2015). The More Technological Approach: Competition Law in the Digital Economy. In Competition on the Internet (pp. 101-108). Springer Berlin Heidelberg.

Ralf, D., \& Roesch, J., (2012). Market Entry into Emerging Two-Sided Markets. Economics Bulletin, 32(3), 2343-2352.

Rintamäki, T., \& Mitronen, L. (2015). Creating Information-Based Customer Value with Service Systems in Retailing. In Service Systems Science (pp. 145-162). Springer Japan.

Rysman, M., (2009). The Economics of Two-Sided Markets. Journal of Economic Perspectives, 23(3), 125-43.

SALAVOU, H. (2015). Competitive strategies and their shift to the future. European Business Review, 27(1).

Salazar, A. J. (2015). Platform Competition: A Research Framework and Synthesis of Game-Theoretic Studies. Available at SSRN 2565337.

Salazar, A. J. (2015). Platform Competition: A Research Framework and Synthesis of Game-Theoretic Studies. Available at SSRN 2565337.

Salminen, J. (2014). Startup dilemmas-Strategic problems of early-stage platforms on the internet.

Samarrokhi, A., Jenab, K., Arumugam, V. C., \& Weinsier, P. D. (2015). Analysis of the effects of operations strategies on sustainable competitive advantage in manufacturing systems. International Journal of Industrial and Systems Engineering, 19(1), 34-49. 
Seamans, R., \& Zhu, F. (2010). Technology Shocks in Multi-Sided Markets: The Impact of Craigslist on Local Newspapers. NET Institute Working Paper.

Singla, M. L., \& Apoorv, D. (2015). How Social Media Gives You Competitive Advantage. Indian Journal of Science and Technology, 8(S4), 90-95.

Staykova, K., \& Damsgaard, J. (2015). The race to dominate the mobile payments platform: Entry and expansion strategies. Electronic Commerce Research and Applications.

Tilson, D., Sorensen, C., \& Lyytinen, K. (2013, January). Platform Complexity: Lessons from the music industry. In System Sciences (HICSS), 2013 46th Hawaii International Conference on (pp. 4625-4634). IEEE.

Treviranus, J., Clark, C., Mitchell, J., \& Vanderheiden, G. C. (2014). Prosperity4All-Designing a Multi-Stakeholder Network for Economic Inclusion. In Universal Access in Human-Computer Interaction. Design for All and Accessibility Practice (pp. 453-461). Springer International Publishing.

Valverde, S. C., Chakravorti, S., \& Fernández, F. R. (2015). The role of interchange fees in two-sided markets: An empirical investigation on payment cards. Review of Economics and Statistics, (0).

Verganti, R. (2009). Design-Driven Innovation: Changing the Rules of Competition by Radically Innovating What Things Mean. Boston: Harvard Business Press.

Wagner, S. M., Eggert, A., \& Lindemann, E. (2010). Creating and appropriating value in collaborative relationships. Journal of Business Research, 63, 840-848.

Wan, Z. H., \& Zhang, M. L. (2014, October). Value propositions in accordance with service-dominant logic and service science: New insights into the Zhongguancun electrics market. In Service Operations and Logistics, and Informatics (SOLI), 2014 IEEE International Conference on (pp. 177-182). IEEE.

Ware, R. (2013). Recent Developments in Two-Sided Markets in the USA and Canada. Webinar, ABA Section of Antitrust Law.

Weiller, C. M., \& Pollitt, M. G. (2014). Platform markets and energy services.

Weyl, E. G. (2010). A price theory of multi-sided platforms. The American Economic Review, $1642-1672$.

Weyl, E. G., \& White, A. (2014). Let the Best. Win: Policy Lessons from the New Economics of Platforms (November 14, 2014).

Weyl, E. G., (2010). A Price Theory of Multi-Sided Platforms. American Economic Review, 100(4), 1642-72.

Wismer, S. (2015). A Note on Price-Parity Clauses in Platform Markets. In Competition on the Internet (pp. 41-52). Springer Berlin Heidelberg.

Yang, D., Sonmez, M. M., Li, Q., \& Duan, Y. (2015). The power of triple contexts on 


\section{Macrothink}

Business Management and Strategy

ISSN 2157-6068

2016, Vol. 7, No. 1

customer-based brand performance-A comparative study of Baidu and Google from Chinese netizens' perspective. International Business Review, 24(1), 11-22.

Yang, M. J., Kueng, L., \& Hong, B. (2015). Business Strategy and the Management of Firms (No. w20846). National Bureau of Economic Research.

Zhu, F., \& Iansiti, M., (2012). Entry into Platform-Based Markets. Strategic Management Journal, 33(1), 88-106.

\section{Appendices}

\section{Appendix 1. Model Figure}

Figure 1. Multi Sided platforms strategies for value capitation and monetization

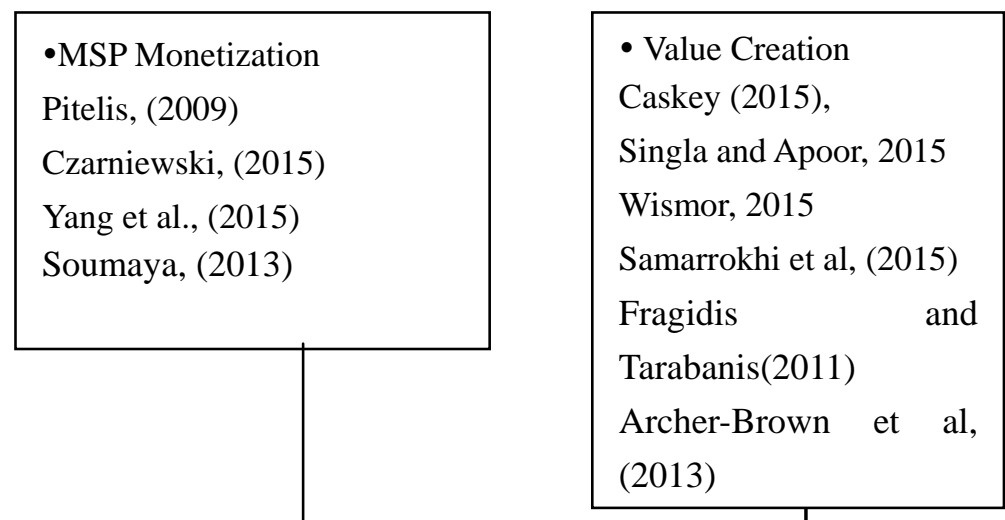

- Value Appropriation

Coff, (2010)

Czarniewski, (2015)

Lepak, Smith and Taylor (2007)

Gimpel, (2015)

Bacache et al, (2015)
PLATFORM STRATEGIES FOR VALUE CAPTATION

Samarrokhi et al, (2015)

Mehta et al., (2015)

Jeitschko \& Tremblay (2015)

Hagiu \& Wright (2011)

\section{FREMIUM STRATEGY}

Pujol (2010)

Bharadwaj et al., (2013)

Liu et al., (2012)

Salminen, J., \& Teixeira (2013)
Above the line strategy

Weyl (2010)

Hagiu \& Wright (2011)

Mehta et al., (2015)

Alkoby et al., (2015)

Tan et al., (2015)
CROSS-PLATFORM

MONETIZATION

STRATEGIES

Pujol (2010)

Bharadwaj et al., (2013)

Shah et al. (2015)

ENVELOPMENT
STRATEGY
Eisenmann et al,
(2010)
Shah et al. (2015)
Kwon and Hong (2015)
Yang et al, (2015)

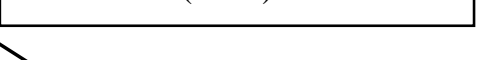




\section{Copyright Disclaimer}

Copyright for this article is retained by the author(s), with first publication rights granted to the journal.

This is an open-access article distributed under the terms and conditions of the Creative Commons Attribution license (http://creativecommons.org/licenses/by/3.0/). 